\title{
Poor Man's Crop? Slavery in Brazilian Cotton Regions (1800-1850)
}

\author{
Thales Augusto Zamberlan Pereira ${ }^{1}$
}

\begin{abstract}
Much of the literature about cotton production in Brazil during the nineteenth century considers cotton as a "poor man's crop" - cultivated by small farmers who did not employ a large slave labor force. However, information provided in population maps from the period between 1800 and 1840 shows that slaves represented half the population in Maranhão, the most important cotton exporter in Brazil until the 1840s. This represented a higher share than in any region in northeast Brazil and was comparable to the slave population shares recorded in the United States' cotton South. This paper shows that, during the cotton boom years (1790-1820), not only was the cotton exported from northeast Brazil to Britain and continental Europe cultivated on large plantations, but also, slave prices were higher in Maranhão than in other Brazilian provinces.
\end{abstract}

\section{Keywords}

Cotton. Slavery. Brazil.

\section{Resumo}

Grande parte da literatura sobre a produção de algodão no Brasil, durante o século XIX, considera o algodão como um produto de "homem pobre" - cultivado por pequenos agricultores que não empregavam uma grande força de trabalho escrava. No entanto, informações fornecidas em mapas populacionais do período entre 1800 e 1840 mostram que os escravos representavam metade da população do Maranhão, o mais importante exportador de algodão do Brasil até a década de 1840. Isso representou uma participação maior do que em qualquer região do nordeste do Brasil, e foi comparável às participações da população escrava registradas na região algodoeira no sul dos Estados Unidos. Este artigo mostra que, durante os anos do boom do algodão (1790-1820), não apenas o algodão exportado do nordeste brasileiro para a Grã-Bretanha e a Europa continental foi cultivado em grandes plantações, mas também os preços de escravos foram maiores no Maranhão do que em outras províncias brasileiras.

\section{Palavras-Chave}

Algodão. Escravidão. Brasil.

\section{Classificação JEL}

J47. N36. N56.

- I'm indebted to the suggestions made by Rafael Marquese, Renato Colistete, William Summerhill, Alejandra Irigoin, and André Villela. The research was funded by the Fundação de Amparo à Pesquisa do Estado de São Paulo (FAPESP project n.2014/04151-6)

${ }^{1}$ Professor - Universidade Franciscana - Endereço: Rua Silva Jardim, 1175 - Santa Maria/RS Brasil - CEP: 97010-491 - E-mail: thales.pereira@unifra.br - https://orcid.org/0000-0002-5245-1167 Recebido: 30/03/2017. Aceite: 25/08/2017

(c) (i) (\$) Esta obra está licenciada com uma Licença Creative Commons Atribuição-Não Comercial 4.0 Internacional. 


\section{Introduction}

In 1863, a New York Times correspondent in Pernambuco reported that, in "the center of the cotton trade" in Brazil, cotton cultivation was "carried on by white men and free half-breeds" (The New York Times 1863). Competition from areas growing sugar and coffee - which after 1850 made slave labor more profitable - led authors such as Stanley Stein and Alice Canabrava to argue that cotton was a "poor man's crop" (Stein 1979, 60; Canabrava 2011, 159; Barbosa 1989, 31). However, there is evidence that until 1820, slaves, not poor free farmers, cultivated the cotton exported from Brazil to Britain and other countries in Europe (Prado Jr 1948, 152). During those decades, large estates controlled cotton production in Maranhão (Mota and Barroso 2017) and several large planters not only held important political positions, but were also involved in the slave trade. Nevertheless, there is still a gap in the literature about what was the relation between the reallocation of slaves to more productive regions and the decline of cotton plantations in the northeast.

This paper shows that slavery in cotton plantations began to decline only in the 1840s, more than two decades after cotton exports stopped growing. Hence, the reduction in Maranhão's slave population was a result, not a cause, of the stagnation in cotton exports. To address the importance of slave labor for cotton production during the first half of the nineteenth century, sections 2 and 3 present population statistics for cotton regions, using the first national census of 1872 as a benchmark to correct for possible biases. Information from population maps shows that until 1840, slaves accounted for half the population in Maranhão, a higher share than that of other northeastern regions of Brazil and comparable to cotton regions in the United States. Sections 4 and 5 discuss two potential sources of slave labor for cotton plantations: population growth and the transatlantic slave trade. Consistent with previous findings, gender ratio imbalance and high mortality rates caused a negative rate of natural growth in the slave population, making planters dependent on the slave trade (Luna and Klein 2004, 7; Mesquita 1987, 136). This was an important demographic difference when compared to the United States, where a positive rate of natural growth was the norm (Steckel 1985; Dunn 2014, 3). Section 6 looks at slave prices and finds an unexpected result: while slave prices were similar throughout Brazil during the first half of the nineteenth century, they were higher in Maranhão during the cotton boom period. Overall, these results show that cotton production in Maranhão mobilized a great 
deal of resources until the 1840s, and that exports were far from being a small-scale economic activity.

\section{Population Statistics}

How do the slave populations in Maranhão and Pernambuco compare to those from other regions in Brazil and the cotton-producing areas of the United States? As the first Brazilian census was compiled only in 1872, data for the provincial population for the first half of the nineteenth century are sparse. ${ }^{1}$ The local town censuses (listas nominativas) provide detailed information on population for some Brazilian regions, but they are not available, to my knowledge, for the cotton growing regions of Maranhão and Pernambuco.

The most widely used source for provincial populations for the early nineteenth century is a census from 1819 by A. R. Veloso de Oliveira. In his study, Oliveira criticizes a previous attempt to estimate the Brazilian population made by Henry Hill, the United States consul in Bahia in 1817, who estimated a population of 3 million for 1815. Since Hill did not have access to the census conducted between 1797 and 1798, which already listed a population of 3 million, Oliveira stated that the consul's estimates were mere speculations (Velloso de Oliveira 1866, 177). Moreover, a previous calculation made by Abbot Corrêa da Serra already established that the Brazilian population in 1810 was already around 4 million inhabitants (J. N. de S. e Silva 1986).

The data provided by Oliveira have been used in important studies on the Brazilian population, such as those by Roberto Simonsen and, more recently, Angus Maddison. ${ }^{2}$ Oliveira's estimates relied on information provided by local parishes from different captaincies during the period from 1808 to $1820 .{ }^{3}$ For example, the region of Ceará-Grande, which belonged to the Archbishopric of Maranhão, collected data for 1808, while a large part of the information for Pernambuco was for 1820. Nonetheless, most records dated from 1814 to 1817. Putting together these maps, the

1 For a description of problems with censuses, see (Alden 1963)

2 According to Maddison, the population in Brazil in 1820 was 4.5 million. (Simonsen 1967, 271; 450) The difference is that Simonsen adds Mato Grosso and Goiás, raising Brazil's population to 4,480,468.

3 They were collected by the "ouvidor ao desembargo do paço." Because the main document is dated June 28th, 1819, it seems that the maps were added later and the final document published on a later date. 
Brazilian population in 1819 was 2,697,099 - without counting the indigenous population, an estimated 800,000 people. Oliveira draws attention to the notorious inaccuracy of the maps, notably the fact that children under seven years of age were not listed, as well as other "known" absences. ${ }^{4}$ Given these limitations, Oliveira added another quarter to the previously estimated population, and a third for two regions (Ceará and Coritiba) that had older population maps. With these adjustments, the population increases to $3,596,132$, and with the addition of 800,000 Indians, the total estimated population in 1819 is $4,396,132$.

Oliveira's survey was also considered the main source of population statistics in Brazil at the time. Henry Chamberlain, British Consul General in Rio de Janeiro, sent Oliveira's figures to the British Foreign Office in September 1822, in a letter containing information on the "supposed population of Brazil." ${ }^{5}$ However, it is worth noting that the numbers provided by Chamberlain, later duplicated by Roberto Simonsen, are for archbishoprics, not captaincies. Since archbishoprics represented a geographical division larger than that of captaincies, their population figures can be misleading. As an illustration, the southern - and distant - bishoprics of Porto Alegre and Santa Catarina were part of Rio de Janeiro's archbishopric. The archbishopric of Maranhão contained the regions of Piauí, Ceará-Grande, and the village of Crato, all of which were not part of the captaincy. Table 1 shows Oliveira's estimates for archbishoprics and for captaincies. The numbers for the captaincies are considered the standard population for Brazil in 1819, adopted by many recent studies (L. Bergad 2007, 9; J. L. R. Fragoso and Florentino 2001, 112; Klein and Luna 2010, 76).

Table 1 - Population of the seven bishoprics in Brazil c.1819

\begin{tabular}{lcccc}
\hline & \multicolumn{2}{c}{ Archbishoprics } & \multicolumn{2}{c}{ Provinces } \\
& Free Population & Slaves & Free Population & Slaves \\
\hline Bahia & 419,432 & 173,476 & 330,649 & 147,263 \\
Rio de Janeiro & 505,543 & 200,506 & 363,940 & 146,060 \\
São Paulo & 269,379 & 122,622 & 167,323 & 81,000 \\
Minas Gerais & 456,675 & 165,210 & 456,675 & 165,210 \\
Pernambuco & 455,248 & 192,559 & 273,832 & 97,633 \\
Maranhão & 261,220 & 201,176 & 66,668 & 133,332 \\
Pará & 121,246 & 51,840 & 92,901 & 33,000 \\
Total & $2,488,743$ & $1,107,389$ & $1,751,988$ & 803,498 \\
\hline
\end{tabular}

Source: See text.

4 “[...] e das pessoas, que deviam andar demais alistadas, sem discutir as causas, que por mui notorias não é preciso referir" (Velloso de Oliveira 1866, 178).

5 From H. Chamberlain 1822 Jan-Sept BNA FO 63/246, p.285 
The main northeast regions, comprising Bahia, Pernambuco, and Maranhão, totaled 30 percent of the Brazilian population and 34 percent of slaves. ${ }^{6}$ Maranhão's population as estimated by Oliveira was 160,000 people, brought to 200,000 people by his "correction" (with 133,332 slaves). This number shows Maranhão with the largest share of slaves of the total population in Brazil: 66.7 percent. Such a high figure led some authors, such as José Jobson de Arruda, to regard it as an indicative of the high income per capita in Maranhão after the cotton boom years (Arruda 1980, 540). Other provinces that had large slaveholdings, such as Bahia, Rio de Janeiro, and Minas Gerais, all had shares of around 30 percent. The unusually high share of slaves in the overall population of Maranhão has raised further questions concerning the mismatch between slave imports and the subsequent decline of the slave population in the province. Daniel Silva, in a study on the Atlantic slave trade to Maranhão, compares the high slave population from 1819 with a much lower number of 97,132 slaves for 1823 (D. B. D. da Silva 2008). ${ }^{7}$ Silva argues that the decline in the slave population could possibly be attributed not only to negative population growth rates, but have been also associated with slave exports from Maranhão to other provinces. When the British attempted to suppress the slave trade on the Brazilian coast, the port of São Luís could have been used as an intermediate source for other major ports in Brazil.

Other estimates, however, raise doubts about the accuracy of Oliveira's high numbers for slaves in Maranhão. Stuart Schwartz, for example, argues that by 1820 Bahia represented the upper level of median and mean size of slaveholding, and that sugar plantations had the highest demand for slave labor (Schwartz 1982, 75). Francisco Mesquita lists a population of 76,500 slaves out of 150,000 inhabitants in Maranhão in 1821 (Mesquita 1987, 130). The data he provides for 1800 and 1840 also reinforces the argument that the estimate presented by Oliveira overstates the slave population by a large margin: there were 34,800 slaves in a total population of 80,000 in 1800 , while the numbers in 1840 were 111,905 and 217,024 , respectively. ${ }^{8}$ Within the space of forty years, these figures suggest an increase of 2.2 percent a year for the free population and 2.9 percent for the slave popu-

6 Another source is Oliveira Vianna, "Resumo Histórico dos Inquéritos Censitários no Brasil.". His figures present even higher slave populations for Bahia and Pernambuco ( $42 \%$ of total slaves).

7 His numbers are from Oliveira Vianna.

8 Mesquita also argues that "several sources" exist for the population of Maranhão in 1822. While not explicit about the sources, he mentions that one of them registers the population for 1822 at 260,000 , a figure even higher than the one presented by Oliveira. 
lation, a trend different from the one presented by Silva and other authors who used Oliveira's figures (D. B. D. da Silva 2008).

Given the differences in population estimates, Table 2 presents some sources that contain information for Maranhão until the official census of 1872. Most of the data was based on an 1870 study by Joaquim Norberto da Souza e Silva, with three exceptions: the population maps of 1798, 1821, and 1838 (J. N. de S. e Silva 1986). These three maps are much more detailed than many estimates presented by Souza e Silva, as some of them are only extrapolations from previous information or plain speculation (Recenseamento do Brasil, 1920 1986, 178).

Data for 1798 are from a population map sent by Governor D. Diogo de Sousa to the Navy and Overseas State Secretary of Portugal in 1799. ${ }^{9}$ Unlike the data gathered by Oliveira, this map includes data on children under seven years of age. Moreover, it also includes those of the indigenous population which were considered "domesticated" - i.e., who lived in villages controlled in some way by the government. Figures for the "wild Indians" were acknowledged to be much higher, and Oliveira stated that they could reach 100,000 people in Maranhão (Velloso de Oliveira 1866).

Table 2 - Population estimates for Maranhão, 1798-1872

\begin{tabular}{cccccl}
\hline Dates & Free & Slaves & Total & Slave Share & Source \\
\hline 1798 & 41,787 & 41,883 & 83,620 & 50.1 & See text \\
1819 & 66,668 & 133,332 & 200,000 & 66.7 & Oliveira \\
1821 & 68,100 & 84,534 & 152,893 & 55.3 & Lago \\
1825 & & 200,000 & & J. P. C. Giraldes \\
1830 & & & & & Joaquim Oliveira \\
1838 & 103,081 & 111,905 & 214,986 & 52.1 & See text \\
1841 & 105,119 & 111,905 & 217,000 & 51.1 & Report Miranda \\
1845 & & & 200,000 & & Dictionary H G B \\
1847 & & & $250-300,000$ & & Report Franco de Sá \\
1856 & & 360,000 & & Candido Machado \\
1864 & & 384,577 & 13.0 & Almanak Maranhão \\
1867 & & 50,000 & & & Souza Brazil \\
1872 & 284,101 & 74,939 & 359,040 & 20.9 & Census \\
\hline
\end{tabular}

Sources: See text.

9 "Ofício do Governador E Capitão Do Maranhão E Piauí, D. Diogo de Sousa Para O Secretário de Estado Da Marinha E Ultramar, D. Rodrigo de Sousa Coutinho" 1799 
For the year 1821, information is provided by Antônio Pereira do Lago, who worked in Maranhão gathering social and economic data. One limitation of his statistics is the absence of children under five years of age, which partially explains why the numbers in Table 4 show no growth in the white population between 1798 and 1821. Lago wrote that immigration largely increased the "white class" in Maranhão after 1808. Immigrants usually arrived in Brazil married and at a young age, so one can assume that their families would have grown. Lago states that he had a hard time finding out the exact number of slaves, which suggests that the numbers for captives were probably underestimated (Lago 1822, 23). If the percentage of children under five from the 1798 population map is used to complement Lago's estimates, the result for 1821 is a population of 169,607 - with 75,795 free and 92,446 slaves. This number for slaves is similar to the number given for 1823 by Oliveira Vianna (Stein 1985, 296).

The statistical map of 1838 is based on a survey conducted by Manoel Joze de Medeiros and published in the province's Presidential report of 1841. This report noted that Medeiros' estimation had limitations because some slaves were declared free men so their owners could avoid being taxed when selling them to other provinces. ${ }^{10}$ Here, it can also be assumed that their numbers are underestimated. Even Maranhão's president João Miranda stated that the total population figures seemed too small, and mentioned "free Africans" that did not appear in civil and parish records. Moreover, no age information is available, so it is not possible to know whether Medeiros' report included children.

10 “Discurso Recitado Pelo Exm. Snr. Doutor João Antonio de Miranda, Prezidente Da Provincia Do Maranhão, Na Abertura Da Assemblea Legislativa Provincial” 1841, 38. 


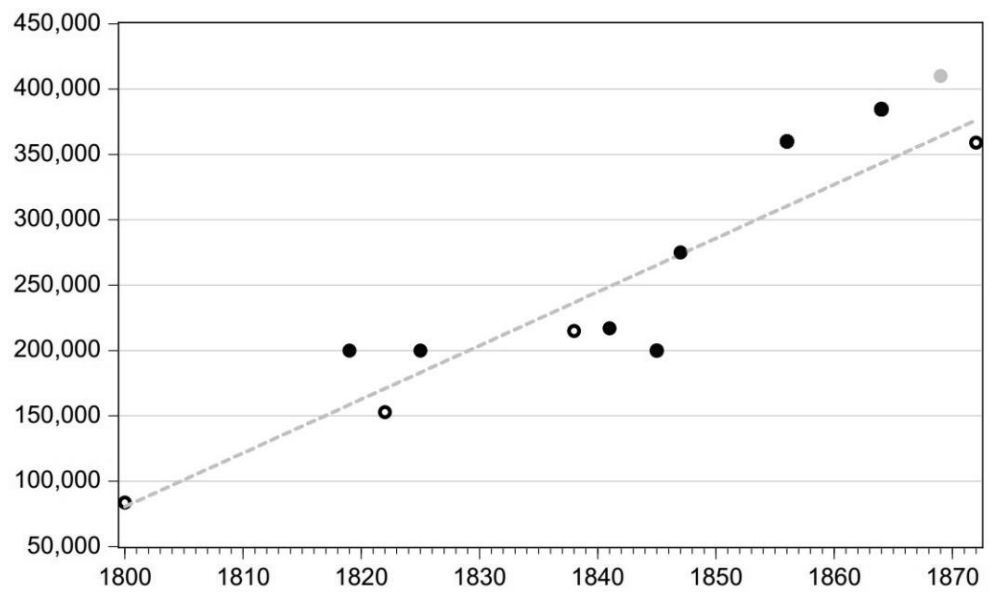

Figure 1 - Population estimates for Maranhão, 1800-1872

Sources: See Table 2.

Figure 1 plots a linear trend between the estimates presented in Table 2 to check whether the population maps from 1798, 1821, and 1838, are not outliers. These maps, along with the 1872 census, which serves as a benchmark for the trend, are represented by empty dots in the figure. The population maps for Maranhão seem to be consistent across time. The light gray dot, not included in the linear trend, is an 1869 population estimate provided by Thomaz Pompeu de Souza Brazil that overstated the total population. This problem is worth mentioning because Souza Brazil's estimation was used in some important publications, such as Robert Conrad's "The Destruction of Brazilian Slavery". As will be shown below, Souza Brazil's figures also overstate the slave population in other provinces, such as Pernambuco, thus posing a limitation on Conrad's argument for the decline in the numbers of slaves in the northeast after 1850.

Before analyzing the population maps for Maranhão in detail, it is important to compare its population statistics with other provinces to verify if slave numbers are consistent across regions. In addition to that, the slave share in the population is a rough measure of economic activity in provinces with large presence of export plantations. Maranhão can be compared with other cotton plantation areas in Brazil, such as Pernambuco, and the southern states in the United States. Table 3 presents population data for Pernambuco. 
Table 3 - Population estimates for Pernambuco, 1810-1872

\begin{tabular}{|c|c|c|c|c|c|}
\hline Dates & $\begin{array}{c}\text { Free } \\
\text { Population }\end{array}$ & $\begin{array}{c}\text { Slave } \\
\text { Population }\end{array}$ & Total & Slave Share & Source \\
\hline 1810 & & & 274,687 & & \\
\hline 1814 & & & 294,973 & & \\
\hline 1815 & & & 339,788 & & \\
\hline 1819 & 273,832 & 97,633 & 371,465 & 26.3 & Oliveira \\
\hline 1823 & 330,000 & 150,000 & 480,000 & 31.3 & Eisenberg \\
\hline 1826 & & & 287,110 & & \\
\hline 1827 & & & 450,000 & & \\
\hline 1829 & 208,832 & 80,265 & 287,140 & 28.0 & Eisenberg \\
\hline 1832 & & & 550,000 & & \\
\hline 1838 & 221,143 & 68,458 & 289,601 & 23.6 & Pres. Report 1841 \\
\hline $1838 b$ & 473,500 & 146,500 & 620,000 & 23.6 & Eisenberg \\
\hline 1842 & 498,526 & 146,398 & 644,924 & 22.7 & \\
\hline 1844 & 600,020 & 400,013 & $1,000,033$ & 40.0 & Souza Brazil \\
\hline 1845 & & & 320,000 & & \\
\hline 1855 & 548,450 & 145,000 & 693,450 & 20.9 & Eisenberg \\
\hline 1858 & & & $1,180,000$ & & \\
\hline 1864 & $1,040,000$ & 260,000 & $1,200,000$ & 21.7 & Souza Brazil \\
\hline 1872 & 752,511 & 89,028 & 841,539 & 10.6 & Census \\
\hline
\end{tabular}

Sources: See text.

One limitation of Pernambuco's statistics is that there is no population map comparable to Maranhão. A similar document, highlighted as a grey dot in Figure 2, clearly underestimates the population for 1838. The other estimate for 1838 on the graph reinforces the argument that the former document does not contain the entire population. In addition to the 1838 population maps, two other observations are not used in the trend (also in gray): Souza Brazil's data from 1844 and 1864. ${ }^{11}$ As argued before, Souza Brazil's data is included in the figure because Robert Conrad used it to show the sharp decline of the slave population in the northeast after 1870 (Conrad 1972, 208). Conrad's source is a book by Agostinho

11 The facsimile source states that the data from Souza Brazil are for the year 1869, but that is probably incorrect, since Malheiros' book is from 1867. See Recenseamento do Brasil, (1920 1986, 411). 
Perdigão Malheiro, published in 1867, which draws on data from Souza Brazil (Malheiro 1867, 3:208). To calculate the population between 1844 and 1864, Souza Brazil used the population in 1815 estimated by Jeronymo M. Figueira de Mello, and with Malthus' assumption that population in a "young" country doubles every 25 years, reached the numbers for both years. ${ }^{12}$ Thus, Souza Brazil's estimates for Pernambuco in 1864 are an extrapolation from fifty years earlier.

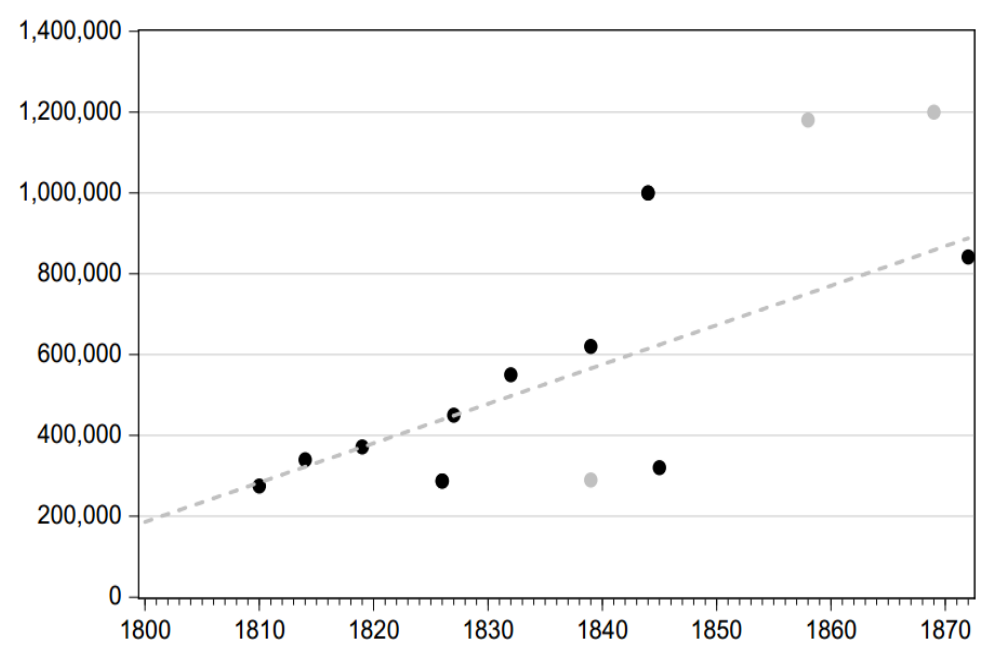

Figure 2 - Population estimates for Pernambuco, 1810-1872.

Sources: See Table 3.

According to the estimations presented in Figure 2, slaves made up about 30 percent of Pernambuco's total population by 1820, declining to 20 percent during the late 1840s. This implies that Maranhão had a considerably higher share of slaves (50 percent) than Pernambuco before 1850. These aggregate comparisons, nonetheless, do not allow us to infer that cotton production between Maranhão and Pernambuco involved a different number of slaves, as sugarcane was the main economic activity in Pernambuco.

12 Malthus population estimates were for the United States and included immigrants. 


\section{Comparison of Populations}

Table 4 presents the population maps of Maranhão, parts of Pernambuco, and Alagoas, along with a census for Rio de Janeiro. ${ }^{13}$ Rio de Janeiro, with its coffee economy, was the most important export economy in Brazil during the first half of the nineteenth century and had a high demand for slave labor. It is expected, therefore, that its relative slave population was among the highest in Brazil. The reason I use the incomplete maps of Pernambuco and Alagoas is that there is an absence of similar documents for Brazilian cotton regions to compare with Maranhão. Though not including the entire population, the share of slaves in Pernambuco is comparable to other estimates presented in Table 3. The data for Alagoas relates to the region of Penedo, which exported cotton through ports in Bahia (Soares and Mello 2006, 19; Tollenare 1905). ${ }^{14}$

Table 4 - Population of Maranhão, Pernambuco, Rio de Janeiro, and Alagoas, 1798-1840

\begin{tabular}{|c|c|c|c|c|c|c|}
\hline & \multicolumn{3}{|c|}{ Maranhão } & \multirow{2}{*}{$\begin{array}{c}\mathrm{PE}^{\star} \\
1838\end{array}$} & \multirow{2}{*}{$\begin{array}{c}\text { RJ } \\
1840\end{array}$} & \multirow{2}{*}{$\begin{array}{l}\mathrm{AL}^{*} \\
1838\end{array}$} \\
\hline & 1798 & 1821 & 1838 & & & \\
\hline Free Population & 41,787 & 68,100 & 103,081 & 213,046 & 183,190 & 28,441 \\
\hline White & 24,073 & 23,994 & 40,114 & 88,593 & 112,983 & 7,997 \\
\hline Indians & 4,094 & 9,687 & 14,476 & 2,094 & 5,615 & 332 \\
\hline Black & 1,332 & 9,308 & 13,782 & 17,821 & 13,387 & 2,294 \\
\hline Mulatto & 12,288 & 25,111 & 34,709 & 102,593 & 51,205 & 17,818 \\
\hline Slaves & 41,883 & 84,534 & 111,905 & 68,458 & 224,012 & 4,213 \\
\hline Black & 30,635 & 77,954 & 95,656 & 50,473 & 210,885 & 2,312 \\
\hline Mulatto & 11,198 & 6,580 & 16,249 & 7,381 & 13,127 & 1,901 \\
\hline Share of Slaves & 50.09 & 55.38 & 51.56 & 23.64 & 55.01 & 12.90 \\
\hline Total Pop. & 83,620 & 152,634 & 214,986 & 289,601 & 407,202 & 32,654 \\
\hline
\end{tabular}

Sources: 1798: Mapa... AHU; 1821: Lago; 1838: Relatório Presidente da Província 1841. *Not total population.

Maranhão had a share of slaves larger than the average of other provinces. In Pernambuco, as stated above, slaves represented 30 percent of the overall population in the 1820 s, declining to 20 percent around 1840. To broaden the comparison, elsewhere in 1830, in Minas Gerais and São Paulo, 36 percent of the population were slaves (Luna and Klein 2004, 10). The high proportion of slaves in Maranhão is most surprising around 1840, when

${ }^{13}$ The population in Table 4 does not contain the city of Rio de Janeiro, which had 137,078 people (J. N. de S. e Silva 1986, 87).

${ }^{14}$ Moreover, local prices for Bahia in the Jornal do Commercio (August 30, Vol 1 n.14 ed.14B 1830 p.3) reported "cotton from Alagoas." 
Rio de Janeiro's coffee economy was growing fast and sugar production in Pernambuco was on its way to overtaking Bahia's output (Stein 1985, 53; Klein and Luna 2010, 85). This is a period, after all, that the crisis in the cotton sector led local newspapers in Maranhão to describe the financial condition of the province as "calamitous" (Viveiros 1954, 1:154).

The region of Penedo in Alagoas had 12.9 percent of slaves, almost half of them mulattos, indicating that the region was not part of the transatlantic slave trade. Rio de Janeiro, by contrast, was highly active in the slave trade, and only 6.2 percent of the slaves were mulattos. Maranhão and Pernambuco had similar shares of enslaved mulattos, of 16.9 and 14.6 percent, respectively. Table 4 also confirms a well-known characteristic of Brazilian slavery; the high numbers, especially when compared to the United States, of free blacks and mulattos (Davis 2014, 52). The number of free colored in the Brazilian population were so strikingly high that, in many regions, their population was larger than the white population (Engerman 2015). The difference was a direct result of high manumission rates, considered an important aspect of the natural decline of the slave population in Brazil and some Caribbean states, such as Cuba (L. Bergad 2007, 104; Engerman 2015). Pernambuco and Alagoas had larger shares of free non-whites -42 and 62 percent, respectively. Again, Maranhão seemed more comparable to Rio de Janeiro than other northeast provinces, with a total population share of 22.5 percent of free non-whites. Henry Koster, who traveled in Brazil at the beginning of the nineteenth century, noted that in São Luís the black population was "much more considerable than at Pernambuco" (Koster 1816, 166).

Maranhão's cotton economy not only had a percentage of slaves comparable to that of the coffee region of Rio de Janeiro, but it also had a share similar to that of the cotton regions in the United States. The high share of slave labor in Maranhão seems to contradict the argument that competition from sugar plantations for workers was an important factor that limited the expansion of cotton production in Brazil (Beckert 2014; Mann 1860). Comparing Brazil's coffee regions and the U.S. south cotton, Richard Graham argued that their labor supply was radically different. In addition to the difference in the population share of free blacks and mulattos, the South had more slaves than Brazil, and they formed a much larger proportion of the population (Graham 1981, 634). However, Graham's comparison was based on the 1860 U.S. census and Brazil's 1872 census. Table 5 shows the slave population of Alabama, Mississippi, and Louisiana 
during the same decades presented in the previous section for cotton production in Brazil. From these numbers, it emerges that Maranhão had a slave population larger than that of all the new cotton South in 1820. Moreover, since the figures for Maranhão's population in 1821 do not include children under the age of five, the number of slaves could have been ten percent higher, as will be shown in the next section.

Table 5 - Population of the United States South, 1800-1840

\begin{tabular}{crrrrrr}
\hline \multirow{2}{*}{ Old South } & \multicolumn{3}{c}{ South Carolina } & \multicolumn{3}{c}{ Georgia } \\
\cline { 2 - 7 } & 1800 & 1820 & 1840 & 1800 & 1820 & 1840 \\
\hline Free Population & 199,440 & 244,266 & 267,360 & 103,280 & 191,333 & 410,448 \\
White & 196,255 & 237,440 & 259,084 & 101,678 & 189,566 & 407,695 \\
Black & 3,185 & 6,826 & 8,276 & 1,019 & 1,763 & 2,753 \\
Slaves & 146,151 & 258,475 & 327,038 & 59,406 & 149,656 & 280,944 \\
Share of Slaves & 42.3 & 51.4 & 55.0 & 36.5 & 43.9 & 40.6 \\
Total Pop. & 345,591 & 502,741 & 594,398 & 162,686 & 340,989 & 691,392 \\
\hline New South & \multicolumn{2}{c}{ Alabama } & \multicolumn{2}{c}{ Mississippi } & Louisiana \\
\hline Free Population & 1820 & 1840 & 1820 & 1840 & 1820 & 1840 \\
White & 86,022 & 337,224 & 42,634 & 180,440 & 84,343 & 183,959 \\
Black & 85,451 & 335,185 & 42,176 & 179,074 & 73,383 & 158,457 \\
Slaves & 571 & 2,039 & 458 & 1,366 & 10,476 & 25,502 \\
Share of Slaves & 41,879 & 253,532 & 32,814 & 195,211 & 69,064 & 168,452 \\
Total Pop. & 32.7 & 42.9 & 43.5 & 52.0 & 45.0 & 47.8 \\
\hline
\end{tabular}

Source: Carter et al., Historical Statistics of the United States.

One must be careful, however, when using aggregate population statistics to compare regions in the United States and Brazil. Unlike Brazil, where slave labor was dispersed across multiple activities during the first decades of the nineteenth century, in the United States slavery was strongly associated with commercial production (Wright 1978, chap. 3). As an example, the slave population of the cotton-growing regions in Alabama was 46.4 percent of the total population in 1820 , a proportion higher than the share presented in Table 5. The Natchez region - in Mississippi - had a slave share of almost 60 percent (Gray 1933, 2:903). In 1852, the American government compiled a survey of the number of slaves employed in cotton production in different states and the result ranged from 20 percent in South Carolina and Louisiana, to 50 percent in Alabama, Mississippi, and Georgia (Ellison 1858, 22). 
It is possible to make some inferences about the number of slaves employed in the cotton industry in Maranhão. According to Lago's data, 69,534 slaves (82 percent of the total slave population) worked in the agricultural sector in 1820 (Lago 1822, 115). Lago does not provide details on the number of slaves in specific regions, but a local planter presented data for Ribeira do Itapecuru, the most important cotton-growing region in Maranhão. During the first decade of the nineteenth century roughly 13,500 people - 16 percent of the population - lived in Ribeira, 85 percent of which were slaves, a third of the slave population of the province (Gayoso 1818, 164).

In addition to numbers for the total slave population, it is necessary to have data on slaveholding patterns in plantations across the Americas if we are to compare how planters in Brazil organized production. Cotton usually required less labor than sugar plantations, but it is also important to analyze whether cotton plantations in Brazil used less labor than other cotton-producing regions, such as the United States. As illustration, the British West Indies were known for having a high number of slaves working on plantations, with many sugar plantations counting on 150 to 250 slaves. By contrast, the average cotton plantation in the southern United States had between 20 and 50 slaves (Engerman 2015, 102). Mota and Barroso show that between 1785 and 1824 most slaveowners had more than 20 slaves in the Ribeira do Itapecuru area, with a third of the sample having more than one hundred slaves per owner (Mota and Barroso 2017, 14). These large slaveholdings, however, were distributed over more than one farm (Da Silva Mota 2007, 56).

Mota and Barroso's sample is limited - 33 slave-owners with a total of 2,958 slaves - but nonetheless it is consistent with other studies arguing that typical cotton plantations in Maranhão and Pernambuco employed 50 slaves per unit, comparable to southern plantations in the United States (Klein and Luna 2010, 68). Louis-François Tollenare wrote in 1816 that the number of slaves on typical cotton plantations ranged between 10 to 30, but he saw plantations with 100 to 150 slaves in Paraíba, and up to 300 in Ceará (Tollenare 1905, 113). However, remarks such as these, made by brief observations of large plantations, can be problematic. For example, Henry Koster reported in 1818 that he met merchants and planters in São Luís, and that one of them, Simplicio Dias da Silva, owned between 1000 and 1500 slaves - a highly improbable number. Even with possible overstatements, the fact is that the average slaveholding pattern indicates that 
cotton planters in Maranhão had the necessary workforce to produce on a scale similar to that of the United States. In 1848, after a decade of low international cotton prices, census sources show that 66 percent of slave -owners in Maranhão still had 20 or more slaves (Marcondes 2005, 183).

What is surprising is that during the early nineteenth century cotton did not have a slaveholding pattern smaller than that of sugar. Schwartz argued that slaveholding patterns in Bahia's Recôncavo were different from those of other sugar plantations in the Americas and, in 1818, 53 percent of slaves lived in groups of 1 to 20. This pattern was normally associated with the United States rather than with the Caribbean. In Louisiana, in 1850, around 20 percent of slaves who worked on sugar plantations lived on estates with fewer than 50 workers. By contrast, in Jamaica, 11 percent lived in units of between 5 and 20 in 1832, and in Trinidad, 17 percent lived in units of under 20 in 1814 (Schwartz 1982, 71). In their studies on Minas Gerais and São Paulo in the 1830s, Luna and Klein found only three owners in Minas who had more than 300 slaves, while the largest slave-owner in São Paulo had 164 slaves (Luna and Klein 2004).

With regard to Pernambuco, Peter Eisenberg observes that travelers at the beginning of the nineteenth century reported that sugar production required 40 slaves, and large estates employed between 100 and 150 slaves, with some employing as many as 300 . During the 1840s, the average number of slaves over 331 plantations was 55, whereas in the 1850s, a survey of 532 plantations reported an average of 20 slaves (Eisenberg 1974, 146). A census carried out in an important sugar production district in Pernambuco in 1857 found that, of 46 sugar mills, the average slaveholding was $72-37$ percent had up to 50 slaves, 43.5 percent had between 50 and 100, and 19.5 percent had more than 100 slaves (Mello 1975, 2:448).

Since studies for cotton regions in the United States usually define a plantation as having a workforce of 20 slaves or more, the evidence presented above shows that in the northeast of Brazil, cotton was not a crop produced by small independent farmers, as seems to be the case for the latter part of the nineteenth century (Battalio and Kagel 1970, 26; Gray 1933, 2:481; Phillips and Smith 2007). The most detailed evidence for cotton plantations, from Mota, suggests that slaveholding patterns in Maranhão were similar to those in the United States. The important difference between these regions was not in slaveholding patterns, but sources of slaves, which is discussed in the next section. 


\section{Gender Imbalances and Population Growth}

Although the slave population in Maranhão and Pernambuco grew at a significant rate during the first four decades of the nineteenth century, the continuous increase in labor supply was highly dependent on the slave trade (Klein and Luna 2010, 149). A higher death rate, combined with a birth rate lower than the national average, were two reasons that impaired the natural growth of the slave population. Harsh work and the higher susceptibility of foreign slaves to local diseases explained most of the variation in death rates. Lower birth rates were connected to gender imbalances, which is a key difference between the history of slavery in Brazil and the United States. With the end of the slave trade in 1807, and with a death rate lower than that of Brazil, in the United States the distribution of enslaved men and women was comparable to that of the free population (Davis 2014, 48). By contrast, Brazil had an active slave trade until 1850 but the slave population was predominantly male, so gender imbalance limited the possibilities for natural population growth (L. Bergad 2007, 43; Engerman 2015).

Analyzing Pernambuco's sugar economy, Peter Eisenberg also linked the negative growth rate of the slave population to conditions similar to those listed above: higher demand for men skewed gender distribution; enslaved women had children at a much lower rate than free women; and there was a high mortality rate among slave infants (Eisenberg 1974, 148). One reason to compare gender distribution is that evidence suggests that sugar plantations represented a harsher reality for workers than the production of other commodities. In the British West Indies, where many islands produced sugar, cotton, and coffee, slaves employed in cotton or coffee had higher birth rates and lower mortality (Ward 1988, 170-79).

Table 6 confirms previous findings regarding gender imbalances in Brazil's slave population. Compared to the cotton south in the United States, Maranhão had a higher share of males in its slave population, although gender imbalance was lower than in other parts of Brazil. ${ }^{15}$ The predominance of cotton plantations in Maranhão explains the lower gender imbalance, because there is evidence that female slave labor was more common

${ }^{15}$ Bergad (2007, p.109) quotes a study from Motta (1988) which presented a "slightly skewed" sex ratio toward males in 1798. While the data is from a São Paulo parish, the information does not seem to confirm Bergad statement. While the white sex ratio was 120,8, the slave was 138 , 8 . See José Flavio Motta, “A Família Escrava e a Penetração do Café em Bananal (1801-1829)," Revista Brasileira de Estudos Populacionais, Vol. 6 (1988), pp. 71-101. 
in cotton than in other crops, such as sugar (Versiani and Vergolino 2003, 367; Fogel 1994, 45). In São Paulo and Minas Gerais around 1830, the average gender ratio between slaves was roughly 158 men for every 100 women, and in regions with more dynamic economic activities, this ratio increased to 180 men for every 100 women (Luna and Klein 2004, 12). Data for Maranhão shows a slave gender ratio of 126 men to 100 women during the first two decades of the nineteenth century (Mota and Barroso $2017,31)$. Since no distinction was made between blacks and mulattos, the gender inequality reported was analogous to the province's average in 1798, which was 125.6 (Gayoso 1818, 164).

Table 6 - Sex ratio in Brazil and the United States, 1798-1840

\begin{tabular}{ccccccc}
\hline Maranhão & White & Indian & \multicolumn{2}{c}{ Mulatto } & \multicolumn{3}{c}{ Black } \\
\hline & & & Free & Slave & Free & Slave \\
1798 & 108 & 96 & 115 & 97 & 108 & 138 \\
1821 & 112 & 112 & 115 & 129 & 91 & 123 \\
1838 & 104 & 102 & 101 & 93 & 110 & 119 \\
\hline Pernambuco & & & & & & 162 \\
\hline 18291 & 110 & & & & 91 & 139 \\
1838 & 74 & 98 & 95 & 91 & & 156 \\
$1842^{1}$ & 110 & & & & & \\
\hline Rio de Janeiro & & & & & & \\
1840 & 108 & 99 & 93 & 106 & Mississippi & S. Carolina \\
\hline \hline United States & National Average & Alabama & Georgia & Louisiana & 102 \\
1820 & 105 & 108 & 103 & 113 & 106 & 94 \\
1840 & 100 & 101 & 98 & 106 & 101 & \\
\hline
\end{tabular}

Sources: (1) Eisenberg, Modernização sem mudança, 150. U.S., Historical Statistics of the United States.

Negative population growth rates resulting from high death rates and gender imbalances demonstrate that a reduction in the captive population would have been inevitable without the transatlantic trade. One way to measure the effect of the transatlantic trade is to build a counterfactual showing what the size of the population would have been during the cotton boom years without the slave trade. Using birth and death information from the 1798 population map, a simple linear model is used to calculate the population in 1821: $N t+1=N t+B t-D t+I t$, in which population size $(N)$ at time $t+1$ is equal to the population size at time $t$ plus births $(B)$ minus deaths $(D)$ plus immigration $(I)$. For white immigrants, the only 
information that Lago presents is that they "increased after 1808" (Lago $1822,23)$. For slaves, the transatlantic traffic data are available from the Slave Voyages Database ("Voyages Database" 2009). In terms of natural population growth, the white population birth rate in 1798 was 26.32 per 1,000 persons, while the death rate was 16.27 per 1,000 persons. For black slaves, the birth rate was 21.41 and the death rate was 26.36 per 1,000 . Since at the time the term "blacks" usually referred to people with African ancestry, the calculation including slave imports does not consider mulattos.

Table 7 shows three estimates for the population in 1821: one using the linear model, one from Lago, and another using Lago's estimate with the addition of children under five, using the 1798 population map as reference. In 1798, the share of children between zero and five was 11.1 percent: 11.3 for the free population, and 9.3 for the slaves. These numbers are consistent with other sources: at the beginning of the nineteenth century probate records from cotton plantations in Maranhão show that 13.2 percent of slaves were children below six years of age (Da Silva Mota 2007, 59). Without the slave trade $(I=0)$, which brought in 41,634 slaves in these two decades, the slave population in 1821 would have been 27,323 ("Voyages Database" 2009).

Table 7 - Estimates for the population in Maranhão, 1821

\begin{tabular}{lccccc}
\hline & $\begin{array}{c}\text { Births per 1000 } \\
(1798)\end{array}$ & $\begin{array}{c}\text { Deaths per 1000 } \\
(1798)\end{array}$ & $\begin{array}{c}\text { Population } \\
\text { (Linear) }\end{array}$ & $\begin{array}{c}\text { Population (w/ } \\
\text { children) }\end{array}$ & $\begin{array}{c}\text { Population } \\
\text { (Lago) }\end{array}$ \\
\hline White & 26.32 & 16.27 & 30,296 & 26,753 & 23,994 \\
$\begin{array}{l}\text { Black } \\
\quad \text { Free }\end{array}$ & 60.81 & 67.57 & 1,340 & 10,524 & 9,308 \\
$\quad$ Slave & 21.41 & 26.38 & 65,926 & 85,749 & 77,954 \\
Mulatto & & & & & \\
$\quad$ Free & 39.06 & 17.17 & 20,220 & 28,752 & 25,111 \\
$\quad$ Slave & 19.91 & 15.00 & 12,534 & 11,541 & 6,580 \\
Total Free & & & 51,856 & 75,795 & 68,100 \\
Total Slave & & & 78,460 & 92,446 & 84,534 \\
\hline
\end{tabular}

Sources: See text.

It is therefore possible to conclude that without the transatlantic trade the slave population in 1821 would have been on average 65 percent lower than it was. Before presenting more information on the slave trade in Maranhão, let us turn to other trends that are noticeable from Table 7. First, a dis- 
tinction between mulattos and blacks was probably introduced between the two periods, as many mulatto slaves seemed to have been classified as black in the 1798 population map. Table 4 also shows this change, indicating a sharp reduction in mulatto slaves in 1821. In addition to that, since free blacks represented only 1.5 percent of the population in 1798 , births and deaths appear to be overestimated. ${ }^{16}$ One question which remains unresolved is whether the free black population had a positive natural growth rate or whether it had a natural negative rate, like the slave population. Lastly, the increase in mulatto and black free population across time is consistent with the findings of the literature, which states that the ability to buy their freedom - which was a major difference between Brazil and the former British colonies - resulted in a higher number of free blacks in Brazil (L. Bergad 2007, 48).

The slave population continued to have negative growth rates and so the dependence on foreign labor continued during the following decades. After Brazil's slave trade came to an end in 1850, the U.S. South was increasingly cited as a successful example of the possibility of a systematic "breeding" to offset declining slave population (Conrad 1972, 32). Others were less optimistic: a local deputy from Maranhão wrote in 1856 that the "Virginia example" for increasing the slave population was unlikely to work in the province. Doubting the planters' capacity to organize such a scheme, the deputy saw the migration of slaves to coffee regions as the inevitable outcome.

\section{The Slave Trade}

The establishment in 1755 of Grão Pará and Maranhão Company, with its investment in cotton and rice plantations, made the Atlantic slave trade to Maranhão lucrative for the first time (Carreira 1988). Between 1760 and 1821, 80,084 slaves arrived in Maranhão through the transatlantic trade. This figure was much lower than the trade with Pernambuco, which received 192,081 slaves, and Bahia, which received 532,104. Nonetheless, the relative importance of the slave trade in Maranhão was larger because of the smaller size of its free population. Bahia was also a 'distribution port'

\footnotetext{
${ }^{16}$ For the second half of the nineteenth century, general mortality did not decrease below 27 deaths per thousand in Recife (Eisenberg 1974, 48).
} 
for other provinces, such as Minas Gerais, something which contributed to increase the number of arrivals.

Figure 3 shows the number of slaves that arrived in Maranhão and the province's cotton exports between 1760 and 1850. The higher number of arrivals between 1780 and 1820 is clearly related to the cotton export cycle. With the expansion of the coffee economy in the 1830s, demand for slaves grew faster than the Atlantic trade could supply. The result was the recruitment of the labor force from less productive regions in northeast Brazil. In 1841, a Presidential report from Maranhão stated that the reduction in the slave population was happening "with certainty." 17 The last arrival of slaves in Maranhão occurred in 1846, with the following year registering the first official export to other provinces (Mesquita 1987, 130; D. B. D. da Silva 2008).



Figure 3 - Slaves imports and cotton exports in Maranhão, 1760-1850

Source: The Trans-Atlantic Slave Trade Database (2009), Maranhão Presidential Report (1861)

Despite the connection between the demand for slave labor and cotton exports, Figure 3 does not imply that the stagnation of exports was directly related to a reduction in the transatlantic slave trade. Slave arrivals

\footnotetext{
${ }^{17}$ From the Provincial Presidential Reports - Maranhão, 1841, p.39. At the capital, there were 402 more deaths of slaves than the free population in 1840. In total, there were 1669 deaths in the capital in that year, a third from children between 1 and 10 years old.
} 
through the Atlantic trade declined in other Brazilian regions after 1820, not only in Maranhão (Klein and Luna 2010, 77). There is evidence showing that the eagerness to buy slaves between 1815 and 1819, when cotton prices were high, led some planters to bankruptcy after cotton prices fell (Viveiros 1954, 1:139). With a reduction of 31 percent in imports and 38.5 percent in exports in 1821, the British consul in Maranhão reported that there was a scarcity of "ready cash" in the province, leading slave dealers to further extend credit to planters. ${ }^{18}$

The reduction in the slave trade after 1820 was not only associated with cotton prices, but also with a forced change in the African regions that supplied the slaves. Daniel Silva argues that the slave trade in Maranhão had a pattern different from the rest of Portuguese America, mainly because it was connected through different wind and ocean currents (D. B. D. da Silva 2008, 485). The different route, similar to the Caribbean Islands, connected Maranhão with slave traders coming from Upper Guinea (Hawthorne 2010). Contemporary reports confirm the predominance of slaves from northwest Africa at the end of the eighteenth century, and also show that slaves who arrived from Guinea were more expensive than those from Angola or Costa da Mina (Gayoso 1818, 243). Thus, the known triangle route between Lisbon, southern parts of the African continent, and Brazil was not the main route used in Maranhão (Alencastro 2000; J. Fragoso 2002, 109). During the cotton boom years, vessels sailing from Lisbon between 1788 and 1815 transported nearly 82 percent of the slaves who arrived in São Luís (D. B. D. da Silva 2008, 489).

The signing of the 1815 treaty with Britain that prohibited the slave trade north of the Equator, and the loss of some African territories meant that Portuguese slave dealers were forced to change their trade routes. The 1815 treaty prohibited the importation of slaves to Brazil under any but the Portuguese flag, which reinforced Portuguese dominance (Bethell 1970, 18). In 1821, Consul Robert Hesketh informed the British government that "the capital employed in the slave trade chiefly belongs to residents in Portugal." 19 Besides, some well-known cotton planters in

\footnotetext{
18 "FO 63/249 - Consuls Alexander Cunningham, Robert Hesketh, and William Pennell, Etc. (Brazil)." 1822, 73)

19 "Consuls Alexander Cunningham, William Pennell, Robert Hesketh, John Lempriere, Cox, and John Parkinson, Etc. (Brazil), FO 63/240” 1821, fol. 202)
} 
Maranhão, such as João Belford, appear on lists of slave vessel owners who sponsored voyages to Maranhão. ${ }^{20}$

The 1807 British prohibition on British subjects trading in African slaves, which affected the Caribbean trade, also reduced the amount of slave supply through the sea routes used by Maranhão's merchants (Ward 1988, 43). The route change is described in a British consular report of 1822, according to which, of the 1,761 slaves who had disembarked in Brazil the previous year, 52 percent had come from Angola (or Benguela), and 18 percent from northwest regions of Africa. Approximately 30 percent of slaves imported to Maranhão came in ships from Rio de Janeiro, Bahia, and Pernambuco. ${ }^{21}$ Some years later, in 1826, the British consul in Maranhão reported that "all the slaves have arrived from Brazil Ports, and the chief part of them are Creole slaves from Ceará, whose masters were forced to bring them here for sale by the great want of provisions in that country." 22

After 1820, when Maranhão's cotton economy began to stagnate, slave labor arrivals steadily declined until a momentary reversal during the 1840s. Silva argues that this decline was in response to the "extension of British efforts to suppress the slave trade into the South Atlantic" (D. B. D. da Silva 2008, 483). Yet, given the series of economic and political crises in Maranhão during the 1830s, British policies would seem a marginal reason for the decline in slave arrivals. For instance, the president of the province warned in 1831 that, with "trade paralysis," public revenues had dropped by almost one third (Viveiros 1954, 1:177). A year after that, the introduction of large quantities of counterfeit copper coins also had a negative effect on foreign trade. On the political side, the Cabanagem revolt, which began in the province of Pará in 1835, also affected commerce in nearby regions such as Maranhão. Newspapers reported in 1835 that rebels in Maranhão and Pará kept capturing new regions and disrupting trade (Jornal Do Commercio 1836, 1, Echo Do Norte 1835, 1). In 1838, the Balaiada established a revolutionary provisional government in the city of Caxias, one of the most important cotton growing regions in Maranhão at the time.

${ }^{20}$ For major merchants from Lisbon between 1790 and 1822, see Pedreira (1995)

21 "From H. Chamberlain (Brazil), FO 63/246" 1822, fol. 176)

22 "FO 13/30 - Arthur Aston, Consuls John Parkinson and Robert Hesketh." 1826, 193) 
Despite these political and economic events, the decrease in slave arrivals only happened decades after the stagnation of Maranhão's cotton plantations had begun. As mentioned before, local politicians and planters knew that the United States had managed to increase its slave population after the end of the slave trade. In addition, the first registered slave export to other provinces occurred in 1846, several years after the instabilities of the 1830s. With these different opportunities for slave demand across time, the next section presents slave-price data and shows that until 1820, slave prices in Maranhão were higher than those in other Brazilian provinces. After 1820, consistent with movements in the export trade, prices converge to Brazil's average and, after 1831, a large aspect of the increase in slave prices was not a result of policy changes, but of increasing inflation.

\section{Slave Prices}

Slave prices were a crucial factor for planters to consider when making investment decisions. Although complaints about high slave prices permeated public debate in the nineteenth century, evidence suggests that prior to the end of the slave trade, in 1850, slave ownership was affordable for people with moderate means (Schwartz 1982, 76). Recent literature points out that slave ownership was more equally distributed than previously thought, which reinforces the argument that slave prices at the beginning of the nineteenth century were not so high in real terms (Klein and Luna 2010; Schwartz 1982; Frank 2004; Marcondes 2009).

In the early nineteenth century, newspapers reported that there had been talk about abolishing the slave trade since the 1810s, but as time passed by and no significant changes were made, these worries eased. In 1830, the editors of Farol Maranhanse argued that those employed in the agricultural sector were "not persuaded that the slave trade abolition is real, since they have been hearing this for many years and [yet] haven't seen any change" (Farol Marenhense 1830). A few months later, however, Brazil's monarch announced that the Brazilian slave trade was illegal and the government would take the necessary measures to stop the traffic - a statement that became law in 1831 (Bethell 1970, 67). The 1831 law, the first official decision to end the slave trade in Brazil, was one of a series of factors that could have affected slave prices between 1780 and 1860 . Before 1819, high cotton prices increased demand for labor and stimulated 
slave imports, but the rising demand from coffee regions and British pressure to abolish the slave trade meant that planters kept expecting future constraints in the labor supply.

How did these changes affect slave prices? In the absence of a reliable price index to account for inflationary shocks, Figure 4 compares nominal slave prices in Maranhão with prices in different areas in Brazil to show that, despite economic dissemblance, regions across Brazil had similar trends in slave prices during the first half of the nineteenth century (L. Bergad 2007; Pereira 2016). For Maranhão, Minas Gerais, and Rio Grande do Sul, series are for men between 15 and 40 years of age, who usually achieved the highest prices. ${ }^{23}$ Information for Maranhão before 1831, which has 2,157 observations, is from Walter Hawthorne's Maranhão Inventories Slave Database, and after 1832, with just two observations, from Francisco Mesquita (Hawthorne 2010, 8; Mesquita 1987, 146). In Mesquita's information, however, it is not clear whether they are for men in the age range used in the previous years. Prices for Pernambuco are decennial averages for the cotton region (Agreste) and include women, a fact which partially explains why prices are lower than those of the other provinces (Resende et al. 2014).

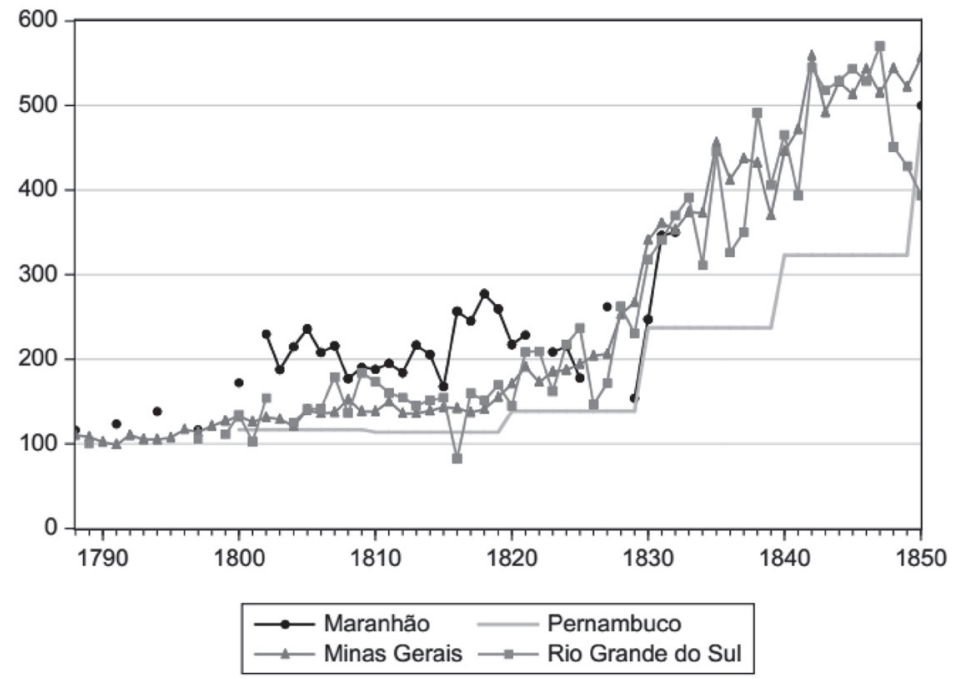

Figure 4 - Slave prices in Maranhão, Pernambuco, Minas Gerais, and Rio Grande do Sul (mil-réis) Sources: MA (Hawthorne 2010; Mesquita, 1987; Mota, 2012); PE (Denslow, 1987; Resende et al, 2014); MG (Bergad, 1999); RS (Pereira, 2016)

${ }^{23}$ Evidence suggests that slaved women worked in cotton sowing. Nevertheless, men represented the largest share of field hands. See Camara $(1799,31)$. 
Figure 4 shows an integrated national slave market, with Minas Gerais and Rio Grande do Sul showing similar means and trends. ${ }^{24}$ Much of the short-term deviation can be explained by differences in sample size, as Bergad's series for Minas Gerais has 16,279 observations, while the price series for Rio Grande do Sul has 1,284. Pernambuco, even with lower prices, also exhibited similar trends: a slow increase until 1830, increasing more rapidly thereafter. During the first decade of the nineteenth century, slave prices in the Agreste region of Pernambuco were even higher than those of other regions of the captaincy, attesting the importance of cotton exports at the time. However, between 1800 and 1820, when cotton exports were growing faster than slave supply, slave prices were higher in Maranhão than in other Brazilian regions. Higher demand and a different slave trade route (as mentioned in the previous section) explain why prices continued to be higher than Brazil's average. Higher prices are also consistent with the evidence that Maranhão did not export slaves to other provinces before the 1840s.

How did slave prices in Maranhão, which were higher than the Brazilian average, compare to international prices? Although using exchange rate conversion as a way to compare prices across economies with different living costs is limited, it can still provide us with useful information about general trends (Williamson 2016, 517). Figure 5 shows that until 1810, nominal slave prices in Maranhão were comparable to those in South Carolina - one of the first cotton states - and to average prices for slaves in New Orleans. These values are also consistent with other international markets at the time: data from Caribbean show slave prices increasing from around $£ 60$ in 1795 to $£ 73$ in 1807 (Eltis, Lewis, and Richardson 2005, 679).

The series named "New Orleans Prime" in Figure 5 is a sample of men aged 18 to 30 (Engerman, Sutch, and Wright 2006, 372). Prices are higher because the age range is shorter than the samples used for Brazil and market prices were usually higher than those recorded in probate records (Mancall, Rosenbloom, and Weiss 2001, 623). For example, data from a list of 1,546 slaves sold in São Luís in 1783, show that average market prices ranged from 135 to 160 mil-réis, with some slaves achieving 200 mil-réis. Planters in Maranhão wrote at the time that the lower prices in

${ }^{24}$ Information for Bahia and São Paulo also present similar prices (Mattoso, Klein, and Engerman 1986; Dean 1976, 55). 
probate records - between 40 and 130 mil-réis - were used only on "court executions or adjudications to creditors" (Gayoso 1818, 243).

Even with the difference in levels between the two New Orleans series, the trends are the same. There was volatility in the first two decades of the nineteenth century, first with the resumption of the slave trade in 1803, and again when cotton prices increased after 1816 (Rothman 2005, 87; Engerman, Sutch, and Wright 2006, 372). Prices increased again during the 1830s, until the 1837 economic crisis (Lepler 2013). In 1836, a U.S. Treasury document about cotton stated that slave prices had almost doubled in the space of one decade, from $£ 94$ on average in the late 1820s to $£ 185$ in 1836 (Treasure Department 1836). In any case, during the first half of the nineteenth century as a whole, slave prices were fairly stable. In Cuba, slave prices also remained relatively constant between 1815 and 1850 , even after the British slave trade came to an end in 1823 (L. W. Bergad, García, and Barcia 1995, 48).

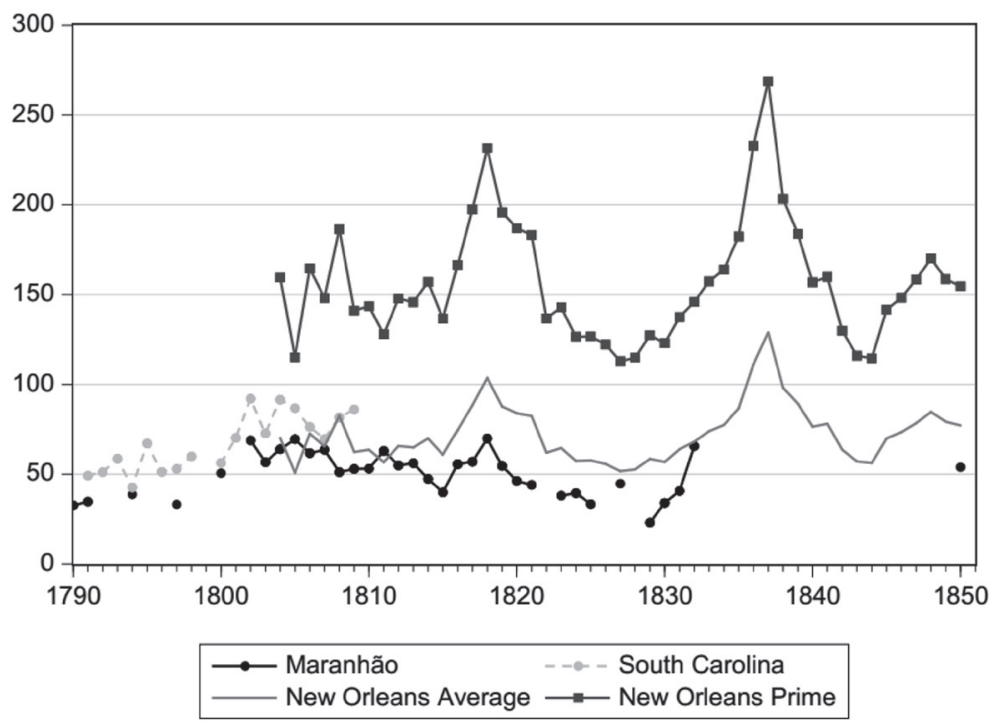

Figure 5 - Slave prices in South Carolina, New Orleans, and Maranhão (£)

Sources: MA (see Figure 4); SC (Mancal et al, 2001); New Orleans (Historic Statistics of the United States, table Bb210, Bb212). 
The stability of slave prices in other American regions suggest that part of the increase in Brazilian prices, especially after 1830, was not related to demand factors, but to inflation. Data from West Africa and Angola (which supplied slaves) show price volatility during the Napoleonic Wars, but the prices in the late 1820s were comparable to those registered in the 1790s (Findlay and O'Rourke 2007, 371; Miller 1986). Nonetheless, Brazilian literature shows that the idea of a constant increase in real slave prices up to 1850 is widely held, especially between 1820 and 1840, when nominal prices doubled (Versiani and Vergolino 2003, 372; Mattoso, Klein, and Engerman 1986, 61). According to Bergad, for example, the expansion of the coffee industry in Rio de Janeiro and São Paulo, as well as British pressure to end the slave trade, caused a rapid increase in prices in Minas Gerais during the 1830s (L. W. Bergad 1999, 167).

However, data in Figure 5 and 6 suggest that the devaluation of the Brazilian currency can provide partial explanation for the increase in prices, especially after 1827 . While the dollar was relatively stable after the end of the Napoleonic Wars, the mil-réis underwent a continuous devaluation against the British pound; around 2.9 percent per annum until the beginning of the Second Reign, in the 1840s (Moura Filho 2010, 20). Large emissions of paper money increased devaluation in the 1820s, especially during the crisis that caused the end of the first Bank of Brazil, between 1827 and 1830 (Summerhill 2015, xiii). It is important to note that at the end of the 1820s, slave prices also fell in the United States, and the devaluation of the mil-réis could have reinforced that trend. Comparing the average prices before and after the monetary crisis (between 1827 and 1831), slave prices in Minas Gerais and Rio Grande do Sul increased by 35 percent, but the continuous growth in nominal prices disappears. 


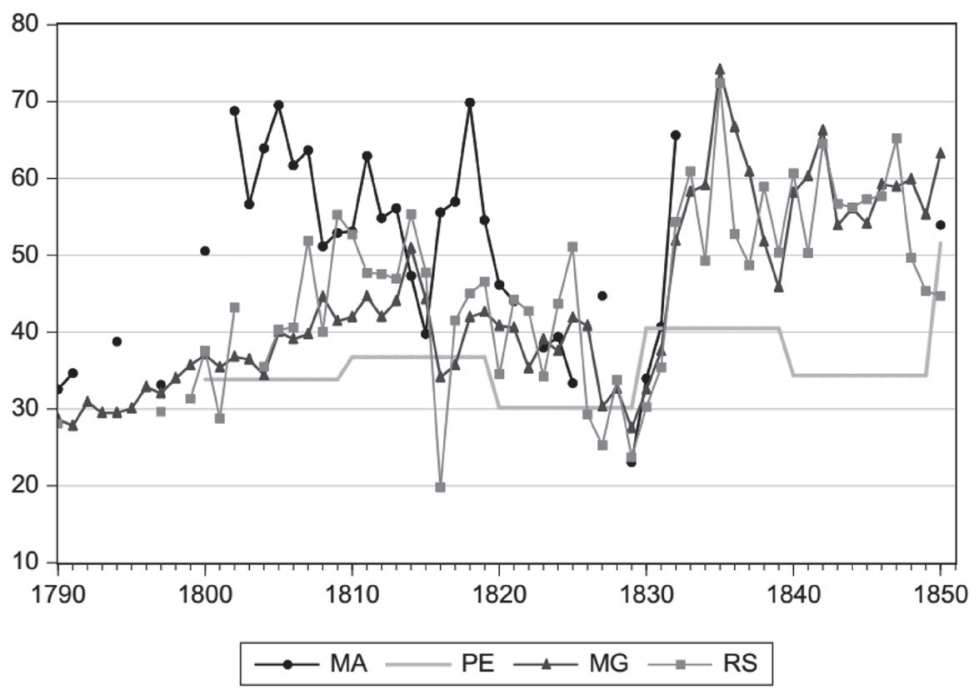

Figure 6 - Slave prices in Maranhão, Pernambuco, Minas Gerais, and Rio Grande do Sul (f)

Sources: See text.

Even with the exchange rate devaluation, part of the increase in prices after 1830 was invariably a response to restrictions in the slave trade. A citizen of the United States who lived in Brazil in the 1830s, exploring diamond mines, wrote that when the slave trade officially ceased, there were few slaves, "to be had at any price" (Anti-Slavery Bugle 1848, 3). This situation led to the emergence of new slave traders that subsequently became very wealthy. While in 1825 the average price for a slave was $200 \mathrm{mil}$ -réis, right after 1830 the average prices rose to 780 mil-réis (730 mil-réis if they were "paid for on sight"). Credit terms of between six and twelve months were usual, but an "industrious man" could have credit up to two years, paying the bills with the labor he had acquired during that time. The report also states that prices fell rapidly between 1833 and 1836, reaching a low point (400 mil-réis) in 1837. These price variations, however, are also closely correlated with changes in the exchange rate at the time, which reinforces the idea that part of the increase in slave prices after 1830 was not related to supply shocks from changes in the slave trade. 


\section{Conclusions}

This paper provided evidence that, far from being a poor man's crop, cotton plantations made extensive use of slave labor until the 1840s - much later than argued in the literature. Information from population maps shows that slaves represented half the population in Maranhão even two decades after cotton exports stopped increasing. This represented a share higher than that observed in any northeast region in Brazil, and was comparable to those recorded in the U.S. South. One important difference compared to the U.S. South was Brazil's dependence on the slave trade. Negative fertility rates in cotton regions confirm previous findings for Brazil, which were that planters needed the slave trade to be able to keep up production with bonded labor.

In terms of how changes in demand and supply affected the labor market, price information suggests that the cotton boom made slave prices in Maranhão increase more than in other regions of Brazil. This finding is important because price data show that slave markets in Brazil had low price dispersion across different provinces during the nineteenth century. Since the Atlantic slave trade set prices until 1850, different routes and labor demand for a booming export staple explain higher prices in Maranhão between 1790 and 1820 .

\section{References}

Alden, Dauril. 1963. "The Population of Brazil in the Late Eighteenth Century: A Preliminary Study." The Hispanic American Historical Review 43 (2): 173-205. doi:10.2307/2510491.

Alencastro, Luiz Felipe. 2000. O Trato dos Viventes. São Paulo, Brazil: Companhia das Letras.

Anti-Slavery Bugle. 1848. “The Slave Trade,” June 9, Vol.3 No.43 edition. Library of Congress, Chronicling America.

Arruda, José Jobson de Andrade. 1980. O Brasil no comércio colonial. Editora Atica.

Barbosa, Luiz Cordelio. 1989. "Cotton in 19th Century Brazil: Dependency and Development.” University of Washington.

Battalio, Raymond C., and John Kagel. 1970. "The Structure of Antebellum Southern Agriculture: South Carolina, a Case Study." Agricultural History 44 (1): 25-37.

Beckert, Sven. 2014. Empire of Cotton: A Global History. First Edition edition. New York: Knopf.

Bergad, Laird. 2007. The Comparative Histories of Slavery in Brazil, Cuba, and the United States. Cambridge University Press. 
Bergad, Laird W. 1999. Slavery and the Demographic and Economic History of Minas Gerais, Brazil, 1720-1888. New York: Cambridge University Press.

Bergad, Laird W., Fe Iglesias García, and María del Carmen Barcia. 1995. The Cuban Slave Market, 1790-1880. Cambridge England ; New York: Cambridge University Press.

Bethell, Leslie. 1970. The Abolition of the Brazilian Slave Trade: Britain, Brazil and the Slave Trade Question. Cambridge: Cambridge University Press.

Camara, Manuel Arruda da. 1799. Memoria Sobre a Cultura Dos Algodoeiros E Sobre O Methodo de O Escolher, E Ensacar. Lisboa: Officina da Casa Litteraria.

Canabrava, Alice P. 2011. O Desenvolvimento Da Cultura Do Algodão Na Província de São Paulo, 1861-1875. São Paulo: EDUSP.

Carreira, António. 1988. A companhia geral do Grao-Para e Maranhao: o comercio monopolista, Portugal-Africa-Brasil na segunda metade do seculo XVIII. Companhia editora nacional.

Conrad, Robert Edgar. 1972. The Destruction of Brazilian Slavery, 1850-1888. University of California Press.

"Consuls Alexander Cunningham, William Pennell, Robert Hesketh, John Lempriere, Cox, and John Parkinson, Etc. (Brazil), FO 63/240.” 1821. The National Archives, Kew.

Da Silva Mota, Antonia. 2007. "A Dinâmica colonial portuguesa e as redes de poder local na Capitania do Maranhão." Recife: Universidade Federal de Pernambuco. http://repositorio.ufpe.br:8080/xmlui/handle/123456789/7245.

Davis, David Brion. 2014. The Problem of Slavery in the Age of Emancipation. First Edition edition. New York: Knopf.

Dean, Warren. 1976. Rio Claro: A Brazilian Plantation System, 1820-1920. Stanford University Press.

“Discurso Recitado Pelo Exm. Snr. Doutor João Antonio de Miranda, Prezidente Da Provincia Do Maranhão, Na Abertura Da Assemblea Legislativa Provincial.” 1841. Maranhão. Center for Research Libraries, Global Resources Network. http://brazil.crl.edu/bsd/bsd/340/.

Dunn, Richard S. 2014. A Tale of Two Plantations: Slave Life and Labor in Jamaica and Virginia. Harvard University Press.

Echo Do Norte. 1835. "Pará," October 18, Vol 2, N.6 edition. Memória Digital, Biblioteca Nacional.

Eisenberg, Peter L. 1974. The Sugar Industry in Pernambuco: Modernization Without Change, 1840-1910. University of California Press.

Ellison, Thomas. 1858. A Handbook of the Cotton Trade: Or a Glance at the Past History, Present Condition, and Future Prospects of the Cotton Commerce of the World. London: Longman, Brown, Green, Longmans, and Roberts.

Eltis, David, Frank D. Lewis, and David Richardson. 2005. "Slave Prices, the African Slave Trade, and Productivity in the Caribbean, 1674-1807." The Economic History Review 58 (4): 673-700. doi:10.1111/j. 1468-0289.2005.00318.x.

Engerman, Stanley. 2015. “40 Years of Slavery Studies.” História Econômica \& História de Empresas 18 (1).

Engerman, Stanley, Richard Sutch, and Gavin Wright. 2006. "Slavery." In Historical Statistics of the United States, Millennial Edition On Line, 2-369; 2-374. Cambridge University Press.

Farol Marenhense. 1830. “Tráfico de Escravos,” January 5.

Findlay, Ronald, and Kevin H. O'Rourke. 2007. Power and Plenty: Trade, War, and the World Economy in the Second Millennium. Princeton, N.J. ; Woodstock, Oxfordshire England: Princeton University Press.

"FO 13/30 - Arthur Aston, Consuls John Parkinson and Robert Hesketh." 1826. The National Archives, Kew.

"FO 63/249 - Consuls Alexander Cunningham, Robert Hesketh, and William Pennell, Etc. (Brazil)." 1822. The National Archives, Kew.

Fogel, Robert William. 1994. Without Consent Or Contract: The Rise and Fall of American Slavery. Norton. 
Fragoso, João. 2002. "Mercados e Negociantes Imperiais: Um Ensaio Sobre a Economia do Império Português (Séculos XVII e XIX).” História: Questões \& Debates 36 (1). http://ojs.c3sl.ufpr.br/ojs/index.php/historia/ article/view/2690.

Fragoso, João Luís Ribeiro, and Manolo Florentino. 2001. O arcaísmo como projeto: mercado atlântico, sociedade agrária e elite mercantil em uma economia colonial tardia : Rio de Janeiro, c.1790-c.1840. Rio de Janeiro: Civilização Brasileira.

Frank, Zephyr L. 2004. Dutra's World: Wealth and Family in Nineteenth-Century Rio de Janeiro. Albuquerque: University of New Mexico Press.

"From H. Chamberlain (Brazil), FO 63/246." 1822. The National Archives, Kew.

Gayoso, Raimundo José de Souza. 1818. Compendio Historico-Politico Dos Principios Da Lavoura Do Maranhão. Paris: Officina de P.-N. Rougeron.

Graham, Richard. 1981. "Slavery and Economic Development: Brazil and the United States South in the Nineteenth Century." Comparative Studies in Society and History 23 (4): 620-55.

Gray, Lewis Cecil. 1933. History of Agriculture in the Southern United States to 1860. Vol. 2. 2 vols. Carnegie Institution of Washington.

Hawthorne, Walter. 2010. From Africa to Brazil: Culture, Identity, and an Atlantic Slave Trade, 1600-1830. Cambridge ; New York: Cambridge University Press.

Jornal Do Commercio. 1836. "Interior: Noticias Do Pará," January 7, 4 edition.

Klein, Herbert S., and Francisco Vidal Luna. 2010. Slavery in Brazil. Cambridge University Press.

Koster, Henry. 1816. Travels in Brazil. London: Longman, Hurst, Rees, Orme, and Brown, Paternoster-Row.

Lago, Antônio Bernardino Pereira do. 1822. Estatística histórico-geográfica da província do Maranhão. Editora Siciliano.

Lepler, Jessica M. 2013. The Many Panics of 1837: People, Politics, and the Creation of a Transatlantic Financial Crisis. New York, NY: Cambridge University Press.

Luna, Francisco Vidal, and Herbert S. Klein. 2004. "Slave Economy and Society in Minas Gerais and São Paulo, Brazil in 1830." Journal of Latin American Studies 36 (01): 1-28. doi:10.1017/S0022216X03007053.

Malheiro, Agostinho Marques Perdigão. 1867. A escravidão no Brasil : ensaio historico-juridico-social. Vol. 3. Rio de Janeiro: Typographia Nacional. http://www2.senado.leg.br/bdsf/handle/id/174437.

Mancall, Peter C., Joshua L. Rosenbloom, and Thomas Weiss. 2001. "Slave Prices and the South Carolina Economy, 1722-1809.” The Journal of Economic History 61 (03): 616-639. doi:null.

Mann, James A. 1860. The Cotton Trade of Great Britain: Its Rise, Progress and Present Extent. Simpkin, Marshall.

Marcondes, Renato Leite. 2005. "Posse de Cativos No Interior Do Maranhão (1848)." Revista Do Instituto Arqueológico, Histórico E Geográfico Pernambucano, no. 61 (July): 169-86.

2009. Diverso E Desigual: O Brasil Escravista Na Década de 1870. FUNPEC.

Mattoso, Kátia M. de Queirós, Herbert S. Klein, and Stanley L. Engerman. 1986. "Research Note: Trends and Patterns in the Prices of Manumitted Slaves: Bahia, 1819-1888." Slavery \& Abolition 7 (1): 59-67. doi:10.1080/01440398608574903.

Mello, José Antônio Gonsalves de, ed. 1975. O Diario de Pernambuco E a História Social Do Nordeste (18401889). Vol. 2. 2 vols. Recife: O Diario de Pernambuco.

Mesquita, Francisco de Assis Leal. 1987. Vida e morte da economia algodoeira do Maranhão: uma análise das relações de produção na cultura do algodão, 1850/1890. Universidade Federal do Maranhão.

Miller, Joseph C. 1986. "Slave Prices in the Portuguese Southern Atlantic, 1600-1830." In Africans in Bondage: Studies in Slavery and the Slave Trade, by Paul E. Lovejoy. Madison: African Studies Program, University of Wisconsin. 
Mota, Antonia da Silva, and Daniel Souza Barroso. 2017. "Economia e demografia da escravidão no Maranhão e no Grão-Pará: uma análise comparativa da estrutura da posse de cativos (1785-1850)." Revista de História, no. 176 (January): 01-41. doi:10.11606/issn.2316-9141.rh.2017.121833.

Moura Filho, Heitor Pinto de. 2010. "Câmbio de longo prazo do mil-réis: uma abordagem empírica referente às taxas contra a libra esterlina e o dólar (1795-1913)." Cadernos de História 11 (15): 9-34. doi:10.5752/P. 2237-8871.2010v11n15p9.

Pedreira, Jorge Miguel Viana. 1995. “Os Homens de Negócio Da Praça de Lisboa de Pombal Ao Vintismo (17551822): Diferenciação, Reprodução E Identificação de Um Grupo Social.” Lisboa: FCSH.

Pereira, Thales A. Zamberlan. 2016. "Was It Uruguay or Coffee? The Causes of the Beef Jerky Industry's Decline in Southern Brazil (1850 - 1889)." Nova Economia 26 (1): 7-42. doi:10.1590/0103-6351/3005.

Phillips, Ulrich Bonnell, and John David Smith. 2007. Life and Labor in the Old South. Columbia, S.C: University of South Carolina Press.

Prado Jr, Caio. 1948. Formação do Brasil contemporâneo. Editora Brasiliense.

Recenseamento do Brasil, 1920. 1986. Resumo Histórico Dos Inquéritos Censitários Realizados No Brasil. Ed. fac-Similada. São Paulo: Instituto de Pesquisas Econômicas.

Resende, Guilherme, Flávio Rabelo Versiani, Luiz Paulo Ferreira Nogueról, and José Raimundo Oliveira Vergolino. 2014. "Preços de Escravos E E Produtividade Do Trabalho Cativo: Pernambuco E Rio Grande Do Sul, Século XIX." Anais do XLI Encontro Nacional de Economia [Proceedings of the 41th Brazilian Economics Meeting]. ANPEC - Associação Nacional dos Centros de Pósgraduação em Economia [Brazilian Association of Graduate Programs in Economics]. http://econpapers.repec.org/paper/anpen2013/030.htm.

Rothman, Adam. 2005. Slave Country: American Expansion and the Origins of the Deep South. Harvard University Press.

Schwartz, Stuart B. 1982. "Patterns of Slaveholding in the Americas: New Evidence from Brazil." The American Historical Review 87 (1): 55-86. doi:10.2307/1863308.

Silva, Daniel B. Domingues da. 2008. “The Atlantic Slave Trade to Maranhão, 1680-1846: Volume, Routes and Organisation.” Slavery \& Abolition 29 (4): 477-501. doi:10.1080/01440390802486507.

Silva, Joaquim Norberto de Souza e. 1986. Investigações Sobre Os Recenseamentos Da População Geral Do Império E de Cada Província de per Si Tentados Desde Os Tempos Coloniais Até Hoje. Ed. fac-Similada. São Paulo: Instituto de Pesquisas Econômicas.

Simonsen, Roberto. 1967. História Econômica Do Brasil (1500/1820). Rio de Janeiro: Brasiliana.

Soares, Mariza de Carvalho, and Priscilla Leal Mello Mello. 2006. “'O resto predeu-se’? História e Folclore: O Caso dos Muçulmanos das Alagoas.” In Visibilidades negras, 14-26. UFAL.

Steckel, Richard H. 1985. The Economics of U.S. Slave and Southern White Fertility. New York: Garland.

Stein, Stanley J. 1979. Origens e evolução da indústria têxtil no Brasil: 1850-1950. Rio de Janeiro: Editora Campus. 1985. Vassouras, a Brazilian Coffee County, 1850-1900: The Roles of Planter and Slave in a Plantation Society. Princeton University Press.

Summerhill, William R. 2015. Inglorious Revolution: Political Institutions, Sovereign Debt, and Financial Underdevelopment in Imperial Brazil. New Haven: Yale University Press.

The New York Times. 1863. "FROM BRAZIL.; The Times in Brazil--The Activity of Pernambuco," December 19.

Tollenare, Louis-François. 1905. Notas dominicaes tomadas durante uma residencia em Portugal e no Brasil nos annos 1816, 1817 e 1818. Impreza do Jornal do Recife.

Treasure Department. 1836. Letter from the Secretary of the Treasury, Transmitting Tables and Notes on the Cultivation, Manufacture, and Foreign Trade of Cotton. Washington, D.C.: Gales \& Sraton. http://hdl.handle. net/2027/uc1.\$b674462.

Velloso de Oliveira, Antonio Rodrigues. 1866. “A Igreja Do Brasil.” Revista Do IHGB XXIX (Parte Primeira): 159-200. 
Versiani, Flávio Rabelo, and José Raimundo Oliveira Vergolino. 2003. "Posse de Escravos E Estrutura Da Riqueza No Agreste E Sertão de Pernambuco: 1777-1887.” Estudos Econômicos (São Paulo) 33 (2): 353-93. doi:10.1590/S0101-41612003000200005.

Viveiros, Jerônimo de. 1954. História do comércio do Maranhão. Vol. 1. São Luís: Associação Comercial Maranhão.

"Voyages Database." 2009. Voyages: The Trans-Atlantic Slave Trade Database. www.slavevoyages.org.

Ward, J. R. 1988. British West Indian Slavery, 1750-1834: The Process of Amelioration. Clarendon Press.

Williamson, Jeffrey G. 2016. "Review Essay on British Economic Growth, 1270-1870; by Stephen Broadberry, Bruce M. S. Campbell, Alexander Klein, Mark Overton, and Bas van Leeuwen.” Journal of Economic Literature 54 (2): 514-21. doi:10.1257/jel.54.2.514.

Wright, Gavin. 1978. The Political Economy of the Cotton South: Households, Markets, and Wealth in the Nineteenth Century. Norton. 